\title{
HEAT REMOVAL USING THE HOLLOW ROOF IN THE JAVANESE HOUSE
}

\author{
Mohammad Pranoto S \\ Architecture Department, University of Pembangunan Nasional "Veteran” Jawa Timur, Surabaya, East Java, Indonesia. \\ E-mail: mprants@yahoo.co.id
}

\begin{abstract}
Ventilation plays a vital role in securing optimum air quality and thermal comfort in buildings. In fulfilling this need, it touches on a wide range of building design and ventilation performance. Early attempts to minimize ventilation energy loss frequently resulted in poor indoor quality and comfort problems. This paper explains about natural air circulation, indoor and outdoor air temperature and also air velocity on the hollow roof in Javanese house, which has a specific shape of geometry and how far that roof can reduce the heat gain in the building. This method using computational fluid dynamics based program have become available to predict airflow and pollutant transport throughout a space. These approximate the space by the grid system containing many control volumes or elements to which numerical equations of flow are applied. And, the result of this research, the cavity roof in Javanese house is able to add indoor air rate velocity, with the average value of $0.5 \mathrm{~m} / \mathrm{s}$, and giving the indoor majority cooling effect average value of $0.55{ }^{\circ} \mathrm{C}$.
\end{abstract}

Keywords: heat removal, hollow roof, Javanese house

\section{INTRODUCTION}

This paper discusses the applicability of the openings in the roof of the house based on traditional Javanese house. According to Lippsmeier (1994), proper placement of the building against the sun, wind, shape and construction as well as the selection of appropriate materials, the indoor temperature can be lowered a few degrees without mechanical equipment. These three elements are influencing the amount of solar radiation global / global irradiance (W/m2).

In addition, there are two elements that have an influence on the amount of the heat resistance: the type of roof material and the design of the roof space, with and without ventilation. The energy-saving building is designed to consume less energy, but still functional, such as by the use of non-conventional energy and energy conservation (Wong, 2007). According to Lechner (2009), there are several factors that will affect the air exchange process that occurs naturally in a room or building. These factors are wind speed and direction outside the building, the temperature, and humidity inside and outside the building, and ventilation holes specification (inlet and outlet position, dimensions, shape and feature supports). Many factors are interrelated and support in creating air exchange either in a room or building. The selection of roof materials and insulation systems in certain climatic regions will also decrease the amount of radiant thermal in buildings which mostly come from the roof, like a hot humid climate such as Surabaya (Lau, et al. 2008)

According to Santosa (1994) and which was then confirmed by Wonorahardjo (2000), in the hot humid climate region that has high humidity causes to be a specific problem including high temperature. Overheating, where outside of the building above the comfort temperature, it is avoided by the human. Passive cooling efforts that have been made, are used to reduce the heat load in the building.

To achieve these conditions is by reducing the impact of unfavorable climatic conditions. There are some things that must be addressed for it. Is the acceleration of

wind flow into the building will be able to remove and reduce the accumulation of heat that occurs?

The warm-humid climate is climate controlled with a difficult character. The main problem in the warm humid climate that the inside air temperature of the building is almost equal to the outside air temperature of the building, where it is caused by high solar radiation. According to Santosa (1994), climate character, especially in Indonesia, can be summed up as follows: The thermal comfort ranges in Indonesia is between $25.4^{\circ} \mathrm{C}$ until $28.9^{\circ} \mathrm{C}$. The comfort condition occurs at night on 11.00 p.m - 05.00 a.m., beyond human active hours.

Natural ventilation is used to purge the building of hot air and cool the building fabric. The methods may include window opening, wind towers (including the hollow roof), solar chimneys and atria. In each case, the system is designed to take advantage of prevailing driving forces. Air movement is also an important aspect of ventilation cooling since it offsets increases in air temperature while maintaining comfort, provided that the increased air velocities are under occupant control. On solar radiation and radiation section, the global irradiance value can be of high value at all the time. Some things that can be concluded is the total radiation on a horizontal surface reaches a maximum at midday.

Solar gain occurs as a result of the absorption of infra-red radiation by surfaces exposed to sunlight. The air temperature of these surfaces can rise considerably, resulting in the heat transfer to the surrounding air stream. The Southern surface will receive the maximum radiation in December while the Northern surface will receive the maximum radiation in June. The Eastern and the Western surface will receive a high radiation throughout the year. Wind speed ranges between $1 \mathrm{~m} / \mathrm{s}$ until $3 \mathrm{~m} / \mathrm{s}$. The wind climate is potential for passive cooling in buildings. According to the driving force theory by Liddament (1996) which was then confirmed by Lechner (2009), natural ventilation can be regulated by the wind thermally. Natural ventilation plan is affected by the position of the openings and value of the pressure distribution. The pressure distribution is affected by the elements: 
Firstly, the stack of pressure means stack effect is built as a result of the difference between the air temperature and water density, between inside and outside of the building (Fig.1). It produces an imbalance in the pressure gradient of inside and outside of air masses which is the result in an outside vertical pressure which is the result in a vertical pressure difference. When the indoor temperature is greater than that of the outdoors, the air passes through the openings at the lowest level of the building and throughout the openings at the highest level. The second one is the pressure of the wind. That means that the wind enters the building and induces a positive pressure on the windward face and negative pressure in the opposite direction in the area throughout of the sides of buildings (Fig.2). Third, mixing between the use of wind and stack pressure, this system is planned to attempt a merger, that the effects of the wind and stack action complement and supported each other.The passive stack and design of atria (space of void) is the solution to the combination of two elements. Alternatively, the pressure distribution can be modified through the mature plan inlet or in the availability of a shelter belt in order to reduce wind effects.

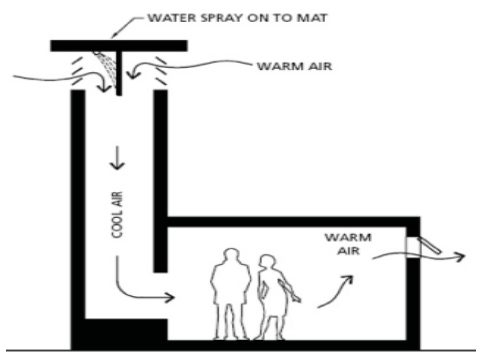

Figure - 1. Cool tower mechanism (Lechner, 2009)
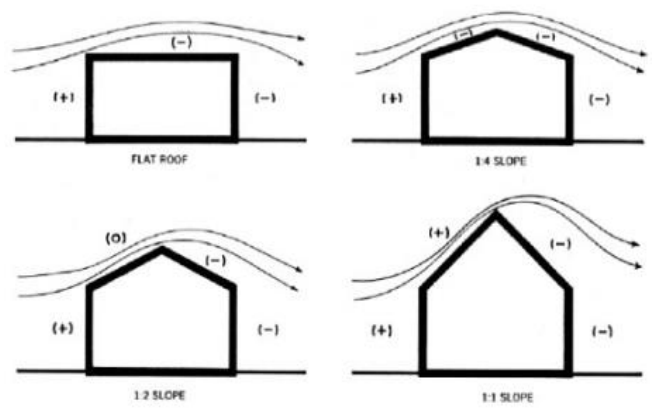

Figure - 2. Pressure of Leeward (-) and Windward (+) (Lechner, 2009)

Ecological roof and the cooling strategy are part of the Javanese's hollow roof home as a method of providing cooling with not always associated with air flow system. The Advantages of this system is a thermal satisfaction that affects the psychological condition in the house. It is also associated with research on thermal performance on roofs with a slope angle of $30^{\circ}$ made of insulated concrete roof tiles in Klang Valley, Malaysia (Zakaria, et al. 2008). Evaporative cooling occurs when air coming into the building across the surface moist or via sprays or wet materials in the area of the opening. The heat is removed from the house by air by the transfer and absorption system. The aim of this study is to reveal and explain the phenomenon of air flow that goes through the hollow roof of Javanese house so as to transfer and remove heat in the house and the air temperature becomes lower than the previous

\section{METHODOLOGY}

As neither the field measurements nor the wind studies provided truly definitive information on the ventilation performance of The Javanese House, an effort to identify other analysis techniques were undertaken. One potential promising technique was computational fluid dynamics (CFD) based program, as was done in this study with CFX-5 (Fig 3). According to Koenigsberger et.al (1973), The movement of air past the skin surface accelerates heat dissipation in two ways: 1). Increasing convective heat loss 2). Accelerating evaporation. The physiological cooling indicator is the wind speed. Wind speed indicators are necessary for physiological cooling based on the relationship three climate variables, namely, the wind speed, the air temperature and the air humidity (Satwiko, 2004)

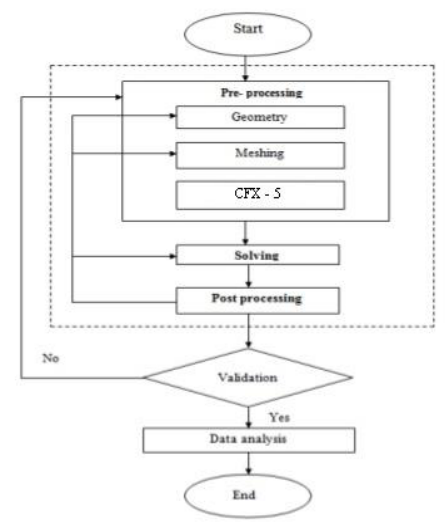

Figure - 3. Flow Chart for CFX-5 (CFD-Based) Simulation Process

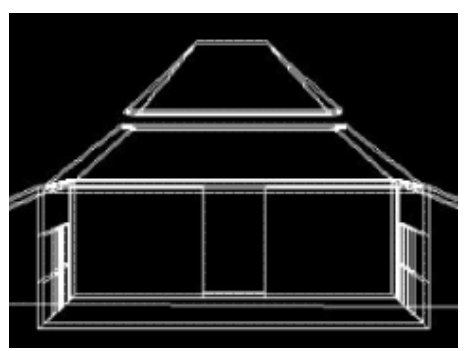

Figure - 4. The model of Javanese House in 3D (from behind)

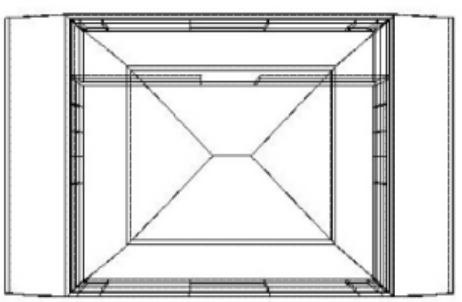

Figure - 5. The model of Javanese House in 3D (from above)

To measure air temperatures experienced in this house, the wind pressure generated by hollow roof depends on the particular position of the opening on the façade, the exact geometry of the building, wind speed, orientation of 
buildings in the direction of the wind, and the shading effects of the nearby buildings (Fig 6).

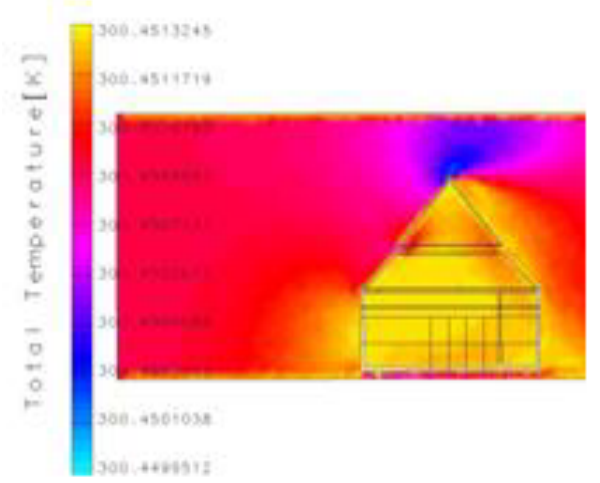

Figure - 6. The air temperature of Javanese House with hollow roof in 2D View

Although the pressure may vary from point to point on the façade, the model will make use of a single averaged value for the pressure at all points on each facade (Fig. 8). Roof hollow opening on the same facade as it will have the same wind flow generated by the external wind pressure. Wind pressure to physiological cooling required when the air humidity reaches 60\% (Aynsley, 1990)

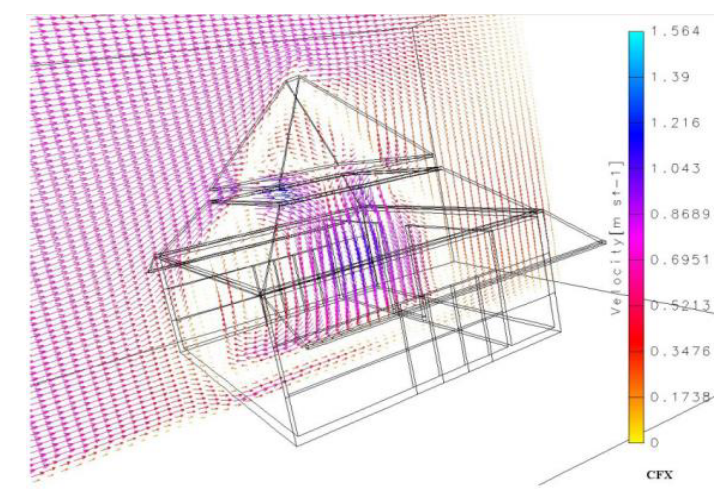

Figure - 7. The pattern and velocity of wind of Javanese House with the hollow roof in $3 \mathrm{D}$ view

Free wind speed is generally measured at a certain reference height above ground level. The relationship between the wind speed at the height of the roof and the reference altitude is determined by the shape of the atmospheric boundary layer (Fig. 7). It is important to realize that the effects of a particularly hollow roof to reduce heat gain caused by radiation outside the roof

The concept mentioned above is able to eliminate the internal heat load due to increased air temperature inside the house. As indicated previously, it is affected by the opening of the effectiveness of the total permeability of the home as determined by the total area of the cavity opening. Airflow is driven by the pressure field is fundamental to the whole flow process. Pressure is maintained by a combination of driven air or forced convection and by buoyancy forces or natural convection. The Roof covering material in coating can help in protecting the roof from ultraviolet rays and reduce the heat from infrared light while saving the range of energy between 20\% until 50\% (Poonia. S.J. et al. 2011)

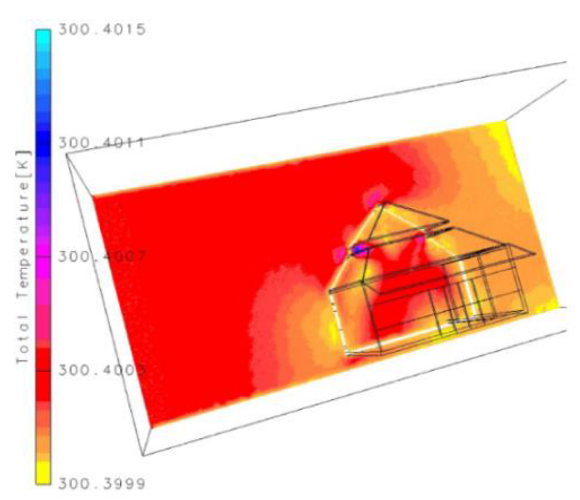

Figure - 8. The air temperature of Javanese House with hollow roof in 3D View

\section{RESULTS}

On the development trend of the performance of the housing at this time, it is rather difficult to reform the traditional buildings in order to obtain optimal natural ventilation. The planning design, the performance of the air in the contemporary home is: Firstly if the outdoor airspeed is low, it brings the movement of hot air, which flows upwards (out of the building) through the ventilation mesh (vertical movement).. And the second, if air moves by applying cross the ventilation system, it moves from the opening area on wall to the other side (horizontal movement) (E, Prianto, at.al 2000)

A hollow roof model is proposed which uses a good balance between empirical data and theoretical equations. The model shows the layout of the building, permeability openings, openings of different height above ground level, wind speed and direction, the temperature difference between indoor and outdoor air as well as the effect of the surrounding area where the building is located. Building using roof ventilation openings are based on the performance data of the building with reference to climate data in Surabaya. Wide openings allowed for the effects of ventilation stacks are openings with a percentage of $5 \%$ of the total roof area (Fig. 9).

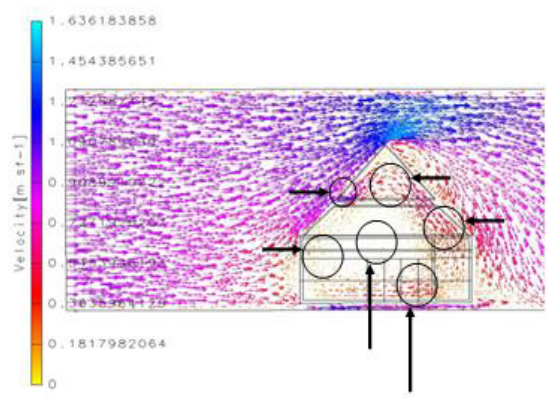

Figure - 9. The pattern and velocity of wind of Javanese House with hollow roof in $2 \mathrm{D}$ view

In the case study, the complex interactions between heat and airflow models are illustrated by investigating the combined effect of roof vents and the dimensions of the cavity. The effectiveness of opening roof area has reduced the heat gradually with the addition of more velocity of the wind.The data of climate is regarded from the data of speed of the wind, the temperature of the air and the direction of the wind of Surabaya City. The average of 
data amount obtained in each type are as follows, namely: Data of average air temperature of hottest month in 2009 until 2014 was in May that was an equal to $27.3^{\circ} \mathrm{C}$, data of the average speed of wind on hottest of month on these years, was $2.3 \mathrm{Knot}(1.18 \mathrm{~m} / \mathrm{s})$. Direction of wind data on the hottest of month in average in these years, was $180^{\circ}$

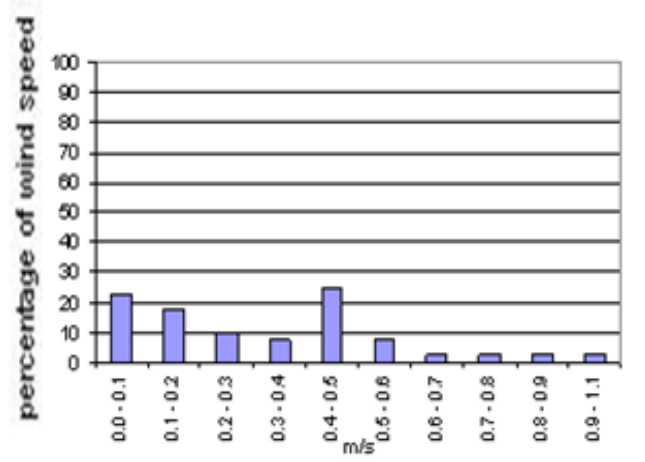

Figure - 10. The value of velocity of wind of Javanese House with hollow roof

The effect of internal heat gain and solar radiation affecting indoors condition through the opening of the roof and other elements of the building envelope is to raise the indoor air temperature (Szokolay, 1980). Effect stacks opposed to relying on thermal power, set the density differences (caused by differences in air temperature) between indoor and outdoor air. This can occur through the opening roof of the cavity: warmer and lighter indoor air will flow from the top and the air will flow through the cracks at the bottom. The principle is the same as in wind generation. The dominant wind speed that occurred when roof vent openings opened by percentage of $5 \%$ is between $0.4 \mathrm{~m} / \mathrm{s}$ until $0.5 \mathrm{~m} / \mathrm{s}$ (Fig. 10).

Special provisions can be made for it in the form of ventilation shafts. The higher the shaft, the greater the cross-sectional area and the larger the temperature difference; the greater the motive power, the more volume of air to be moved. That is the phenomenon of the condition as described in the table below (Table-1).

Table -1: Condition of Indoor space of roof of Javanese House

\begin{tabular}{|l|c|l|l|l|}
\hline Condition & $\begin{array}{l}\text { Wind } \\
\text { speed } \\
(\mathbf{m} / \mathbf{s})\end{array}$ & $\begin{array}{l}\text { Air } \\
\text { Temp. } \\
\left({ }^{\circ} \mathbf{C}\right)\end{array}$ & $\begin{array}{l}\text { Opening } \\
\text { percentage } \\
(\mathbf{\%})\end{array}$ & $\begin{array}{l}\text { Dimension } \\
\text { of opening } \\
(\mathbf{m} 2)\end{array}$ \\
\hline Existing & 0 & 27.75 & 0 & 0 \\
\hline $\begin{array}{l}\text { With } \\
\text { cavity } \\
\text { roof }\end{array}$ & $\begin{array}{c}0.5 \\
\mathrm{~m} / \mathrm{s}\end{array}$ & 27.45 & 5 & 7 \\
\hline
\end{tabular}

According to Koenigsberger (1977) which was then confirm by Moore (1993) and Allard (1998), the indoor wind movement are able to occur due to the differences in wind dynamics and the temperature of the air. Movement of the wind occurs due to differences in air pressure between the two sides, which the natural wind is going to move from high air pressure to low air pressure (Santamouris and Asimakopoulus, 1996). In the hollow roof in the Javanese house, the wind pressures on house surfaces, which is the direction of the wind (windward) will give positive air pressure $(+)$ in that building, while on the edge, back and top of the building, it is going to give the negative air pressure(-).

\section{CONCLUSION}

The provision of air flow and the removal of heat by mass transfer are the first two tasks of ventilation. Where a relatively small volume of air exchange is adequate, the problem is easily manageable. The passive cooling systems described here include not only the well-known traditional techniques mentioned above but also more sophisticated modern techniques (with the CFD-based program) and this technique should be considered as an aid to thinking and should be used intelligently, not only as a mechanical tool. Without cross-ventilation, there will be no appreciable air movement. When the inlet opening is large, the velocity of entering air will be low, but the volume of air flow will be large. Given an elevational area, the highest air velocity within the room is obtained with a small inlet and large outlet opening. As much as possible, passive cooling uses natural forces, energies, and heat sinks. The result and analysis on the condition of the Javanese house with the hollow roof can turn out to lower the air temperature inside the building. The hollow roof in the Javanese house (with $5 \%$ of percentage of the opening area of the roof), can provide the dominant speed of wind changes on that house, from its state of original (existing condition) at $0 \mathrm{~m} / \mathrm{s}$ to $0.5 \mathrm{~m} / \mathrm{s}$, and can remove the heat or in the other hand is providing effect of cooling of $0.55{ }^{\circ} \mathrm{C}$, reducing the average of temperature of the air from the value of $27.7^{\circ} \mathrm{C}$, to the value of $27.2^{\circ} \mathrm{C}$.

\section{REFERENCES}

Lippsmeier. G. 1980. Tropenbau Building In The Tropics. Van Nostrand Reinhold. NY.

Satwiko. P. 2004. Solar-Wind Generated Roof Ventilation System (S iVATAS) for Humid Climate, The International Journal of Ventilation. Vol.3. No.3. December 2004.(ISSN 1473-3315)

Santosa. M. 1994. Geometrical Plan Design and Roof Construction As Main Aspects Of The Housing Living Comfort Level, Research Report, Research Institutions, ITS Surabaya, pp 7-13.

Givoni. B. 1976. Man, Climate and Architecture, Applied Science Publisher Ltd, Essex, UK

Poonia. S. Jethoo. AS. Poonia, MP. 2011. A Short Review On Energy Conservation In Buildings Using Roof Coating Materials For Hot An Dry Climates". Universal Journal of Environmental Research and Technology. Vol.1.Issue 3: 247-252.

Wong. N.H. 2007. A Study of Effectiveness of Passive 
Climate Control In The Naturally Ventilated Residential Buildings In Singapore. The Journal of Environment and Buildings 42. 2007. 1395-1405. Department of Building. School of Design and Environment. National University of Singapore. The Republic of Singapore 117566. Singapore

Lau. A.K.K. Elias. S. and Lim. C.H. 2008. The Thermal Performance Evaluation of Roofing Systems and Materials in Malaysia Residential Development, In: Proceeding of $9^{\text {th }}$ SENVAR and $2^{\text {nd }}$ ISESEE Humanity and Technology Shah Alam. Malaysia. 387-395

Aynsley. R and Spruill. M. 1990. The Thermal Comfort Models For Outdoor Thermal Comfort In Warm Humid Climates and Probabilities of Low Wind Speeds, Journal of Wind Engineering and The Industrial Aerodynamics 36 1990. pp.481-488

Zakaria. N.Z. Peter. W. and Ahmad. R. 2008. Thermal and Energy Evaluation of Roofing and Ceiling Insulation For The Residential Building in Tropical Climate. In : Proceeding of $9^{\text {th }}$ SENVAR and $2^{\text {nd }}$ ISESEE Humanity Technology. Shah Alam. Malaysia, 577

Prianto. E. Bonneaud.F. Depecker. P. Peneau.P.J. 2000 Tropical Humid Architecture in The Natural Ventilation Efficient Point of View. The Reference of Traditional Traditional Architecture in Indonesia, The International Journal of Architecture Science, Vol.1. No. 2. P.80-95.

Moore. F. 1993. Environmental Control System: Heating, Cooling, Lighting, McGraw - Hill Inc, USA

Santamouris. M. and Asimakopoulus. D. 1996. Passive Cooling of Building. James and James Science Publishers. London.

Allard. F. 1998. The Natural Ventilated Building Design Handbook. James and James Science Publisher. London. pp 32-33.

Szokolay. S.V. 1980. Environmental Science Handbook For Architects and Builders, The Construction Press, Lancaster, pp 381 -383.

AEA Technology plc. 2002. Introduction to CFX-5, CFX International, AEA Technology plc, 8.19 Harwell Didcoot, Oxfordshire OX11 0RA, United Kingdom.

Koenigsberger. O. Ingersol. T.G. Mayhew. A and Szokolay. S.V. 1973. Manual Of Tropical Housing and Buildings. Part 1: The Climatic_Design. Bombay: Orient Longman

Climate Datas of Surabaya City from 2009 - 2014, Geophysics and Meteorological Board (BMG) Juanda Climate Station

Wonorahardjo. S. 2000. A Study Of Roof Ventilation Types and Their Influence On Indoor Thermal Comfort. SENVAR 2000. Edt: Santosa. M. The Laboratory Of
Architectural Science and Technology. Department Of Architecture. Faculty Of Civil Engineering and Planning. ITS Surabaya 